\title{
The Influence of IFRS Adoption
}

\author{
Feng $C . X u$
}

\begin{abstract}
:
This paper aims to present a thorough theoretical coverage to the subject studied by focusing on the concepts in companies as general, and accounting disclosure, test the selected hypothesis, obtain satisfying results to the research in an appropriate manner that consists with the problem studied and hypotheses, and find a reasonable answer to main question that is (Does IFRS adoption in the large banks improve financial reporting quality?) based on the main hypotheses which are financial reporting quality has not improved after IFRS adoption in the large banks, and financial reporting quality has improved after IFRS adoption in the large banks.
\end{abstract}

Keywords: IFRS, Quality, Accounting Information, Banks

\section{Research Methodology}

a) Research Problem:

This research focuses on the impact of IFRS on financial information. Thus, the research problem can summarized according to the following question: Does IFRS adoption in the large banks improve financial reporting quality?

b) Research Objectives:

The objectives of this research are demonstrated by the following points:

- Presenting a thorough theoretical coverage to the subject studied by focusing on the concepts in companies as general, and accounting disclosure.

- Testing the selected hypothesis of this research.

- Obtaining satisfying results to the research in an appropriate manner that consists with the problem studied and hypotheses of this research.

c) Research Importance:

The importance of this research can be defined according to the following points:

- The importance of ideas included within the theoretical section of this research.

- Provide some perspectives for the researchers, who should realize the importance of the factors that used in this research.

- The outcomes and results that can be obtained from the subject studied. 
d) Research Hypothesis:

According to the research problem and objectives we can specify the basic hypotheses of this research as following:

- Hypothesis 0 : Financial reporting quality has not improved after IFRS adoption in the large banks.

- Hypothesis ${ }_{1}$ : Financial reporting quality has improved after IFRS adoption in the large banks.

e) Research Limitations:

This research has three important limitations:

- The assumption that if the IFRS adoption has resulted in an increase or decline in accounting quality is conditional on the presumption that the change in the accounting quality measures is driven principally by the changes in managerial discretion or the exercise of judgment rather than by changes in properties of accounting naturally resulting from the new standards.

- IFRS adoption period results are based only on the two years of data, 2014 and 2015. As such, it is conceivable that over a longer period the effects of this research information may not persist as implementation guidance and preparer familiarity with IFRS standards increase over time and/or there are improvements in the institutional structures of financial reporting in banks.

\section{Literature Review}

a) IFRS Adoption:

According to Penman (2002), who stated that, the quality of the earnings is based on the earnings persistency and predictive ability of the earnings. They view that earnings are to be of high quality when the firm's past earnings are strongly associated with its future earnings. Other researchers view earnings to be of higher quality when earnings are value relevant, for example, the earnings are strongly associated with the security's price.

Voulgaris, Stathopoulos, and Walker (2011) believed that IFRS adds noise to accounting numbers that makes reported earnings less useful for evaluating managerial performance. This is mainly due to the adoption of the fair value accounting, which potentially makes accounting numbers more value-relevant, but also more volatile and sensitive to market movements.

In addition, they believed that whilst the IFRS may have made accounting earnings more useful for stock market valuation purposes, this may have been achieved at the expense of other purposes that accounting serves, i.e., stewardship/performance contracting.

In other words, as accounting numbers are designed to conform more and more closely to market values, the less they are able to provide information over what is complementary to market values for evaluating performance.

Similarly, Kim and Suh (1993) believed that if accounting numbers become more sensitive to market movements than the accounting related signals, provides little additional information about managing performance, as they no longer screen out market related noise. 
Moreover, the move to fair value accounting makes accounting earnings figures more volatile. If the increase in earnings volatility is driven by events almost entirely outside the control of management then this also reduces the attractiveness of the earnings, as a basis for performance-based contracts.

Ball (2006) and Choi and Meek (2005) believed that the IFRS has the potential to facilitate cross border comparability, increase reporting transparency, decrease information costs, reduce information asymmetry and thereby increase the liquidity, competition and efficiency of markets.

In addition, Ball (2006) notes that the fair value orientation of the IFRS could add volatility to the financial statements in the form of both good and bad information. The latter consisting of noise which arises from inherent estimation error and possible managerial manipulation.

Ahmed, Neel, and Wang (2012) states that, the effects of the mandatory IFRS adoption on the accounting quality critically depend upon whether the IFRS is of higher or lower quality than domestic GAAP and how they affect the efficacy of enforcement mechanisms. By a higher quality standard they mean a standard that either reduces managerial discretion over accounting choices or inherently disallows smoothing or overstatement of earnings.

If IFRS is of higher quality than domestic GAAP, and they are appropriately enforced, then we expect mandatory adoption of IFRS to improve accounting quality. On the other hand, if IFRS are of lower quality than domestic GAAP or if IFRS weaken enforcement (for example, because of increased discretion or flexibility), then it would expect to reduce accounting quality.

b) The Impact of IFRS Adoption on Accounting Quality:

The impact of IFRS on the accounting quality is an empirical question. This is supported by Leuz, Nanda, and Wysocki (2003), Barth, Landsman, and Lang (2008), Christenson, Lee, and Walker (2008), and Chen, Tang, Jiang, and Lin (2010), who believed that accounting choices that result in greater income smoothing, greater management of earnings to meet a target, and overstatement of earnings (or delayed recognition of losses) as compromising faithful representation of the underlying economics therefore, reduce accounting quality. Similarly, Barth et al. (2008) presents three reasons why the adoption of the IFRS could lead to improvements in the accounting quality:

- The IFRS eliminates certain accounting alternatives, thereby reducing managerial discretion. This could reduce the extent of opportunistic earnings management and thus improve accounting quality.

- The IFRS is viewed as principles-based standards and thus are potentially more difficult to circumvent. For example, under a principles-based standard it should be more difficult to avoid recognition of a liability through transaction structuring.

- The IFRS permits measurements such as, use of fair value accounting, which may better reflect the underlying economics than domestic standards.

At the same time, Barth et al. (2008) also note two reasons why the adoption of IFRS may reduce accounting quality: 
- The IFRS could eliminate accounting alternatives that are most appropriate for communicating the underlying economics of a business, thus forcing managers of these firms to use less appropriate alternatives thus resulting in a reduction in accounting quality.

- Because IFRS is principles-based, they inherently lacked detailed implementation guidance and thus afford managers greater flexibility.

For some important areas such as revenue recognition for multiple deliverables, the absence of implementation guidance would significantly increase discretion and allowable treatments, depending upon how they are interpreted and implemented.

c) Accounting Quality under IFRS:

Ahmed, Neel, and Wang (2012) stated that previous studies focused on a number of institutional factors that have impacted accounting quality. The evidence in previous studies suggests that the accounting quality is generally higher in strong enforcement countries relative to weak enforcement countries.

This in turn suggests that there may be systematic differences in the effects of the IFRS adoption in strong enforcement versus weak enforcement countries. However, it is very difficult to make definitive predictions because the change in accounting quality from the pre-IFRS periods to the post-IFRS periods depends upon:

- Whether the IFRS is of higher or lower quality than the domestic GAAP, for example, whether they increase or decrease overall managerial discretion.

- On the efficacy of enforcement mechanisms. For strong enforcement countries, if IFRS is of higher quality than domestic GAAP and they are appropriately enforced, expect an improvement in accounting quality. For example, if IFRS eliminates accounting alternatives that were opportunistically used by the managers, elimination of these alternatives would improve the accounting quality.

They also believed that strong enforcement partition has a significantly higher average rule of law score. That is, firms in the strong enforcement partition have lower (higher) average total assets, book-to-market, growth rates, and leverage (market values) relative to the weak enforcement partition.

In addition, they believed that if the IFRS are of lower quality than domestic GAAP in the sense that they increase managerial discretion, accounting quality would decline even in strong enforcement countries given that managers have incentives to exercise their discretion in their own interests. Furthermore, the accounting quality may decline after the mandatory IFRS adoption because principles-based standards are looser, on average, than domestic standards and thus, more difficult to enforce.

Nelson (2003) concludes that aggressiveness of reporting decisions increases with the imprecision of the relevant reporting standard, based on a survey-based research. In addition, they believed that even in strong enforcement countries, relatively loose standards can result in more opportunistic choices.

This is supported by Paananen and Lin (2008), who find that evidence of a decline in accounting quality in Germany, strong enforcement country, after the mandatory IFRS adoption. Ball (2006) believes that in the absence of suitable enforcement mechanisms, real 
convergence and harmonization is infeasible, resulting in diminished comparability.

Collectively, these studies suggest that loose standards can lead to a decline in accounting quality even in strong enforcement countries. On the other hand, in the weak enforcement countries, previous research studies such as of Leuz et al. (2003), Burgstahler et al. (2006), Holthausen (2009), and Hope (2003) argue that rules or standards are generally not effective, that is, without adequate enforcement, even the best accounting standards will be inconsequential.

Extending this logic, even if the IFRS is of a higher quality than a domestic GAAP, they are unlikely to result in improvements in accounting quality in weak enforcement countries because they are unlikely to be properly enforced. Therefore, do not expect a change in accounting quality after the mandatory IFRS adoption for firms in weak enforcement countries.

Armstrong et al. (2009) and Soderstrom and Sun (2007) believed that cultural, political and business differences may also continue to impose significant obstacles in the progress towards this single global financial communication system, since a single set of accounting standards cannot reflect the differences in the national business practices arising from differences in the institutions and cultures.

d) Variables Affected Financial Reporting under IFRS:

Ahmed, Neel, and Wang (2012) also finds in their study that there is an increase in income smoothing for the IFRS firms relative to benchmark firms after the mandatory IFRS adoption.

Specifically, they find a significant decrease in the volatility of net income, the volatility of net income relative to the volatility of cash flows, and the correlation between cash flows and accruals for the IFRS firms relative to benchmark firms. Second, they find evidence of a significant increase in aggressive reporting of accruals for the IFRS firms relative to benchmark firms. Third, they find evidence of a significant reduction in timeliness of loss recognition for the IFRS firms relative to benchmark firms consistent with the increase in reporting aggressiveness suggested by the accrual tests.

Finally, they believed that their evidence is consistent with meeting or beating earnings targets after controlling for variable, management, in benchmark firms. In addition, they stated that while the evidence is not fully consistent across all proxies, taken together, the results suggest that the accounting quality decreased after the mandatory IFRS adoption.

Ball et al. (2000) finds that timeliness of loss recognition decreases significantly after the mandatory IFRS adoption relative to benchmark firms. Similarly, Paananen (2008) and Paananen and Lin (2008) find in their results that there is a decrease in financial reporting quality, an increase in earnings management, and a reduction in timeliness of loss recognition in Germany, following mandatory IFRS.

Jeanjean and Stolowy (2008) find no decline in the pervasiveness of the earnings management in Austria and UK but an increase in France. Christensen et al. (2008) finds that the incentives dominate standards in determining accounting quality around mandatory IFRS adoption. Daske et al. (2008) shows that the capital market benefits around the mandatory adoption of the IFRS are unlikely to exist primarily because of IFRS adoption.

Daske (2006) finds no evidence that the IFRS adoption decreases a firm's cost of 
capital. Atwood et al. (2010) finds that the earnings reported under the IFRS are no more or less persistent and are no more or less associated with the future cash flows than earnings reported under the local GAAP. In addition, they suggest that the documented increase in analyst forecast accuracy following the IFRS is not the result of the differences in the underlying persistence of those earnings.

e) IFRS Variables from Literature:

Paananen and Lin (2008) in their IFRS research have used variables related to financial reporting quality, earnings management, and a timeliness of loss recognition to assess financial reporting quality.

Barth et al. (2008) in their IFRS research has used variables of volatility of net income, ratio of volatility of net income to the volatility of cash flows, and the correlation between cash flows and accruals. Ball et. al (2000) in their IFRS research has used timely loss recognition (measured by net income and the asymmetric incorporation of economic gains and losses into the reported income) to assess accounting quality.

Beaver (2002) in their IFRS research has used value relevance (statistical association between accounting information and market prices or returns) as a variable to assess accounting quality. Ahmed, Neel, and Wang (2012) in their IFRS research study has used variables related to income smoothing: volatility of net income, volatility of net income relative to volatility of cash flows, correlation between cash flows and accruals.

\section{Conclusions:}

Globally, the use of the IFRS in financial reporting is the requirement for many countries, primarily due to the influence of investors/shareholders demand, cost minimization in financial reporting, security listings requirements, foreign investments, free trade, and global competition.

However, the question of whether such a global transition towards a single set of accounting standards has been met by the presumed benefits of higher accounting quality and comparability yet remains unanswered.

To contribute to our knowledge in this important topic we have investigated whether mandatory IFRS adoption in the five Kurdish banks improves quality of the financial reporting.

This research finds that under IFRS, increase in earnings quality due to increase in value relevance (earnings influence to market price); increase in persistency and predictability in earnings and cash flows; and increase in earnings to shareholder value.

However, it also finds that, decrease in accruals and timeliness loss of recognition (reduce in income smoothing), and decrease in the accounting valuation usefulness (earnings to book value per share).

Moreover, this research finds that the results are consistent with both information and comparability effects under the two approaches (statement of operations and the statement of financial position). 


\section{References:}

1. Ahmed, A., Neel, M., and Wang, D., (2010). Does Mandatory Adoption of IFRS Improve Accounting Quality? Preliminary Evidence. Working paper.

2. Al-Nasrawi, Salam A., and Thabit, Thabit H. (2020). The Influence of the Environmental Factors on the Adoption of the International Accounting System IAS/IFRS: Case of Iraq, Journal of Accounting, Finance and Auditing Studies, 6(1), 66-85.

3. Barth, M., Landsman, W., and Lang, M. (2008). International Accounting Standards and Accounting Quality, Journal of Accounting Research, 46(3), 467-98.

4. Basu, S. (1997). The Conservative Principle and the Asymmetric Timeliness of Earnings, Journal of Accounting and Economics, 24(1), 3-37.

5. Bernstein, L., and Wild, J. (2000). Financial Statement Analysis: Theory, Application and Interpretation, New York: McGraw-Hill Companies, Inc.

6. Bodie, Z., Kane, A., and Marcus, A. (2004). Essentials of Investments, $5^{\text {th }}$ ed., McGraw-Hill.

7. Bryman, A., and Bell, E. (2003). Business Research Methods, New York, Oxford University Press.

8. Buck, T., Bruce, A., Main, B., and Udueni, H. (2003). Long Term Incentive Plans, Executive Pay and UK Company Performance, Journal of Management Studies, 40(7), 1709-1727.

9. Chen, H., Tang, Q., Jiang, Y., and Lin, Z. (2010). The Role of International Financial Reporting Standards in Accounting Quality: Evidence from the European Union, Journal of International Financial Management \& Accounting, 21(3), 220-278.

10. Choi, F., and Meek, G. (2005). International Accounting, 5th Edition, Prentice-Hall.

11. Dawood, Harith A., Thabit, Thabit H., Jasim, Yaser A. (2015). Proposed Approach to Apply a Green Balanced Scorecard at the Iraqi Environment, 2nd International Conference on Ecology, Environment, and Energy, Ishik University, Erbil, Iraq.

12. Dufera, A. (2010). Financial Performance Evaluation (A Case Study of Awash International Bank (AIB)), Mekelle University, Mekelle, Ethiopia.

13. Epstein, Barry J., and Jermakowicz, Eva K. (2007). Interpretation and Application of International Financial Reporting Standards, John Wiley \& Sons.

14. Fielding, Nigel G., and Fielding, Jane L. (1985). Linking Data, Qualitative Research Methods, 4, 96-101.

15. Helfert, Erich A. (2010). The Nature of Financial Statements: The Cash Flow Statement, Financial Analysis - Tools and Techniques - A Guide for Managers.

16. Jasim, Yaser A., and Raewf, Manaf B. (2020). Information Technology's Impact on the Accounting System, Cihan University-Erbil Journal of Humanities and Social Sciences 4 (1), 50-57.

17. Jasim, Yaser A., Awqati, Ali J., Hussen, Russel A., and Lubis, Nurul Izzah (2020). Job Costing: Empirical Evidence of Bakery Production, Accumulated Journal (Accounting and Management Research Edition), 2(2), 179-189.

18. Jeanjean, T., and Stolowy, H. (2008). Do Accounting Standards Matter? An Exploratory Analysis of Earnings Management before and after IFRS Adoption, Journal of Accounting and Public Policy, 27(6), 480-94.

19. Kieso, D., Warfield, T., and Weygandt, J. (2010). Balance Sheet \& Statement of Cash Flows, Intermediate Accounting, JohnWiley \& Sons, New Jersey, USA. 
20. King, Alfred M. (2006). Fair Value for Financial Reporting, New Jersey, John Wiley $\&$ Sons.

21. Lefebvre, R., Simonova, E., and Scarlat, M. (2009). Fair Value Accounting: The Road to Be Most Travelled, Issue in focus, Certified General Accountants Association of Canada, CGA.

22. Leone, M. (2009). The FAS159 Mulligan, CFO Magazine.

23. Neely, M.C. and Wheelock, D.C. (1997). Why Does Bank Performance Vary Across States?, Federal Reserve Bank of St. Louis Review, 79(2).

24. O'Kelly, B. (2008). Commercial Banks: How Fair is Fair Value?, Accountancy Ireland, 40(3).

25. Paananen, M., and Lin, C. (2007). The Development of Accounting Quality of IAS and IFRS over Time: The Case of Germany, Working paper, University of Hertfordshire.

26. Pannese, D. and Delfavero, A. (2010). Fair Value Accounting: Affect on the Auditing Profession, Journal of Applied Business Research, 26(3).

27. Peters, D., Raad, E., and Sinkey, F. (2004). The Performance of Banks in Postwar Lebanon, International Journal of Business, 9(3), 259-28.

28. Ronen, J. (2002). Post-Enron Reform: Financial Statement Insurance and GAAP Revisited, Stanford Journal of Law, Business and Finance, 8(1).

29. Ross, S. A., Westerfield, R. W, and Jaffe, J. (2005). Corporate Finance. McGraw-Hill Inc., $7^{\text {th }} \mathrm{Ed}$.

30. Saleh, A. S., and Z. Rami (2006). Islamic Banking Performance in the Middle East: A Case Study of Jordan, Working Paper 06-21, Department of Economics, University of Wollongong.

31. Samad, A., and Hassan, K. (2000). The Performance of Malaysian Islamic Bank During 1984-1997: An Exploratory Study, Thoughts on Economics 10(1).

32. SBDC (2004). Financial Statement Analysis for Small Businesses: A Resource Guide, Virginia Small Business Development Center Network, USA.

33. Sheikh Waqas, A. (2005). Financial Statement Analysis of Bank Falah, Virtual University Pakistan, Pakistan.

34. Thabit, Thabit H. (2019). The Influence of Mobile Information Technologies in Enhancing the Electronic Audit, The $3^{\text {rd }}$ International Scientific Conference, The World Islamic Sciences and Education University, Amman, Jordan.

35. Thabit, Thabit H., Aldabbagh, Lukman M., and Ibrahim, Laith K. (2019). The Auditing of Sustainable Development Practices in Developing Countries: Case of Iraq, Revista AUS, 26(3), 12-19.

36. Thabit, Thabit H., and Abbas, Nazar H. (2017). A Proposed Fuzzy Logic Based Framework for E-Accounting: Evaluation in Iraq, Qalaai Zanist Scientific Journal, 2(6), 732-751.

37. Thabit, Thabit H., and Al-Nasrawi, Hamed A. (2016). The Role of International Financial Reporting Standards in Reducing the Financial Risks, International Journal of Latest Engineering Research and Applications, 1(5), 73-82.

38. Thabit, Thabit H., and Jasim, Yaser A. (2016). A Manuscript of Knowledge Representation, International Journal of Social Sciences \& Economic Environment, 1(1), 44-55.

39. Thabit, Thabit H., and Jasim, Yaser A. (2016). The Role of Environmental Accounting Disclosure to Reduce Harmful Emissions of Oil Refining Companies, 
The $3^{\text {rd }}$ International Conference on Energy, Environment, And Applied Science, Ishik University, Erbil, Iraq.

40. Thabit, Thabit H., and Jasim, Yaser A. (2017). Applying IT in Accounting, Environment and Computer Science Studies, LAP- Lambert Academic Publisher, Germany.

41. Thabit, Thabit H., and Jasim, Yaser A. (2019). The Challenges of Adopting EGovernance in Iraq, Current Research Journal of Social Sciences and Humanities, 2(1), 31-38.

42. Thabit, Thabit H., and Raewf, Manaf B. (2016). The Impact of Voluntary Disclosure on SMEs in Developing Countries, Journal of Global Business and Social Entrepreneurship, 4(5), 19-31.

43. Thabit, Thabit H., and Raewf, Manaf B. (2017). Applications of Fuzzy Logic in Finance Studies, LAP- Lambert Academic Publisher, Germany.

44. Thabit, Thabit H., and Raewf, Manaf B. (2018). The Evaluation of Marketing Mix Elements: a Case Study, International Journal of Social Sciences \& Educational Studies, 4(4), 100-109.

45. Thabit, Thabit H., and Solaimanzadah, Alan (2018). The Role of SOX Act in Enhancing the Internal Control Systems of Kurdistan Banks, International Conference on Accounting, Business, Economics and Politics, Ishik University, Erbil, Iraq.

46. Thabit, Thabit H., Hadj Aissa, Sid A., and Harjan, Sinan A. (2016). The Use of Fuzzy Logic to Measure the Risks of ICT in E-Audit, Revue des Recherches Economiques, No. 15 , pp. 30-46.

47. Thabit, Thabit H., Hadj Aissa, Sid A., and Jasim, Yaser A. (2021). The Impact of Green ICT Adoption in Organizations of Developing Countries, Al-riyada for Business Economics Journal, 7(1), 9-18.

48. Thabit, Thabit H., Ibraheem, Laith K., and Majed, Ahmed W. (2019). Proposed Framework for Auditing Sustainable Development Practices in Iraq, $8^{\text {th }}$ International Scientific Conference, Baghdad College of Economic Sciences University, Baghdad, Iraq.

49. Thabit, Thabit H., Ishhadat, Heba S., and Abdulrahman, Omar T. (2020). Data Governance Based on COBIT2019 Framework to achieve Sustainable Development Goals, Journal of Techniques, 2(3), 9-18.

50. Thabit, Thabit H., Solaimanzadah, Alan, and Al-abood, Muath T. (2017). The Effectiveness of COSO Framework to Evaluate Internal Control System: The Case of Kurdistan Companies. Cihan International Journal of Social Science, 1(1), pp. 44-54.

51. Thabit, Thabit H., Solaimanzadah, Alan, and Mohammed, Mohammed A. (2019). Determining the Effectiveness of Internal Controls in Enterprise Risk Management based on COSO Recommendations, the $2^{\text {nd }}$ International Conference on Accounting, Business, Economics and Politics, Ishik University, Erbil, Iraq.

52. Veron, N. (2008). Fair Value Accounting is the Wrong Scapegoat for This Crisis, Revue d'Economie Financière and Risques.

53. Zenaida, R., and Fernando, R. (2000). Theoretical and Analytical Aspects of Longitudinal Research, PSC Discussion Papers Series, 14(5), Article 1. 